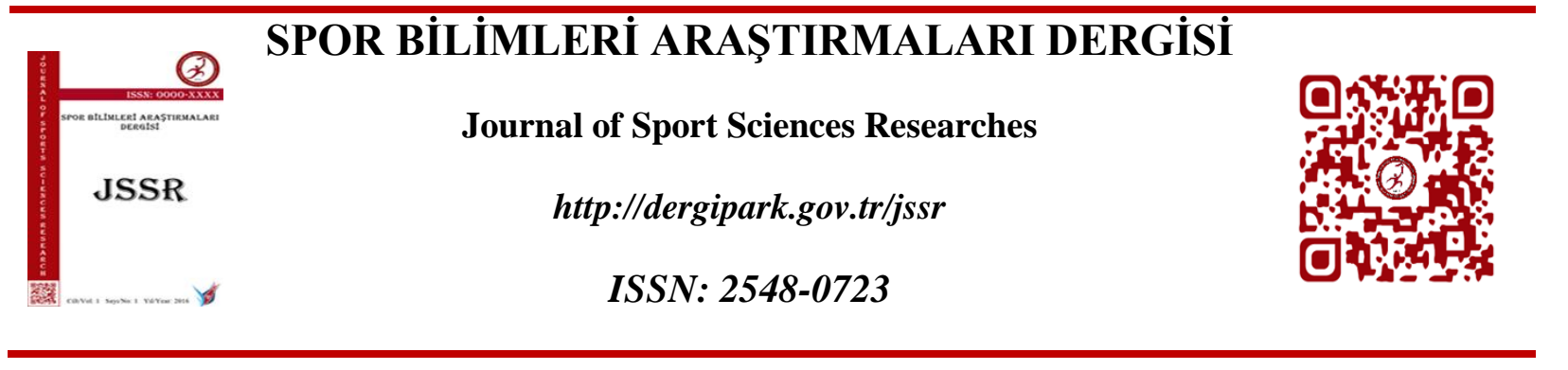

\title{
Türkiye’nin Ulusal Gençlik ve Spor Politikalarının, Sürdürülebilirliğin Sosyal Boyutuyla İncelenmesi*
}

\author{
Velittin BALCI ${ }^{1}$, Yasemin GÖK ${ }^{2}$, Halil Erdem AKOĞLU ${ }^{3 \dagger}$ \\ ${ }^{I}$ Ankara Üniversitesi, Spor Bilimleri Fakültesi, ORCID iD: 0000-0003-3145-9618 \\ ${ }^{2}$ Spor Genel Müdürlüğü, ORCID iD: 0000-0002-6488-0559 \\ ${ }^{3}$ Niğde Ömer Halisdemir Üniversitesi, Beden Eğitimi ve Spor Yüksekokulu, ORCID iD: 0000-0002-0818-7143
}

\section{$\ddot{\mathbf{O} z}$}

Orijinal Makale

Kalkınma anlayışına göre sürdürülebilirlik, ülkelerin çevresel, ekonomik ve sosyal hedeflerindeki ortak paydayı göstermekte ve geleceği de içeren bu ortak hedefler, bireylerin daha iyi bir yaşama ilişkin beklentilerinin temel ihtiyaçlar aracilı̆ı̆lla karşılanmasına yönelik imkânlar sunmaktadır (Kalkınma Bakanlı̆̆ı, 2017). Sürdürülebilirliğin sosyal boyutu, insan ve topluma yönelik olup, amacı ise toplumsal yaşamda sosyal ve kültürel sistemlerin devamlılığını ve dengeli olmasını sağlamaktır. Sosyo-kültürel sisteme sahip olan gençlik ve spor alanlarında da ulusal politikalar, temel hedeflerin yanı sıra, sağlıklı nesillerin yetiştirilmesi, halk sağlğı̆ın korunması ve toplumsal barışın korunması, toplumsal bütünleşmenin arttırılması, boş zamanların değerlendirilmesi, sosyal katılımın teşvik edilmesi, sosyal dışlanmayla mücadele, toplumsal gelişimin güçlendirilmesi gibi sürdürülebilirliğin sosyal boyutlarına yönelik önemli sosyal hedefler içermektedir. Bu çalışmanın amacı, Türkiye'nin Ulusal Gençlik ve Spor Politikalarının, sürdürülebilirliğin sosyal boyutu açısından incelenmesi ve analiz edilmesidir. Nitel araş̧ırma modeline göre tasarlanan araştırmada durum analizi (case studies) deseninden yararlanılmıştır. Yapılan doküman incelemesi sonucunda elde edilen veriler betimsel ve içerik analizi yöntemine göre analiz edilmiştir. Analiz sonucunda, Türkiye'de gençlik ve spor alanlarında yürürlükte olan ulusal politikalarda eşitlik, eğitim, sağllk, istihdam, barınma, kültürel değerler, eğlence ve serbest zaman ve güvenlik gibi sosyal boyuta yönelik politika hedeflerinin daha çok soyut açıklamalarla betimlenmiş olduğu görülmüştür. Ulusal gençlik ve spor politikalarında sosyal boyuta yönelik belirlenen hedeflerin, uygulamaya dönük somut hedefler olması, toplumsal kalkınmanın desteklenmesi ve teminat altına alınması açısından önemlidir.

DOI: $10.25307 /$ jssr.399823

Gönderi Tarihi: 28.02.2018

Kabul Tarihi: 20.06.2018

Online Yayın Tarihi:30.06.2018 (10.25307/jsst 399823

Anahtar kelimeler: Gençlik politikası, spor politikası, sürdürülebilirlik, sosyal sürdürülebilirlik.

\footnotetext{
* Bu çalışma 23-26 Kasım 2017 tarihlerinde Manisa'da gerçekleştirilen Dünya Spor BilimleriAraştırmaları Kongresi’nde sözel bildiri olarak sunulmuştur.

† Sorumlu Yazar: E-mail: erdemakoglu@ hotmail.com, Tel: +905384090553.
} 
Balcı, V., Gök, S., ve Akoğlu, H. E. (2018). Türkiye'nin ulusal gençlik ve spor politikalarının, sürdürülebilirliğin sosyal boyutuyla incelenmesi. Spor Bilimleri Araştırmaları Dergisi, 3(1), 9-22.

\title{
The Investigation of The National Youth and Sports Policies of Turkey in The Perspective of The Social Dimension of The Sustainability
}

\begin{abstract}
According to the perspective of the sustainable development, sustainability shows a common ground in environmental, economic and social objectives, while the common objectives including future is to be enable to satisfy fundamental human needs and expectations for a better life. The social dimension of the sustainability is focused on human and plays a crucial role in maintaining continuity of social-cultural systems in a social life. The aim of the social dimension in the sustainability is to enable social and cultural systems balanced constantly. National policies applied at both youth and sports fields include social objectives aimed at social dimension of sustainability such as raise healthy generations, sanitation, protecting social peace, enhancement of social cohesion, leisure time activities, encouraging social participation, struggle against social exclusion, strengthening social development etc besides primary objectives. The aim of this study is to examine the National Youth and Sports Policies of Turkey from a viewpoint of social dimension of sustainability. In the research designed according to qualitative research model, case studies pattern was used. The data obtained as a result of the document review were analyzed according to the descriptive and content analysis method. For this purpose, it was tried to analyse how to conceptualize and to apply strategically social indicators within the social dimension of sustainability in national youth and sport policies in both youth and sport fields in Turkey. As result of the analyse, it was revealed that policy objectives aimed at social dimension such as equality, education, healthy, employment, cultural values, recreation and leisure time, security were indicated with intangible descriptions in the national policies applied at youth and sports field in Turkey. It is more significant that objectives aimed at the social dimension at national youth and sports policies with regards to ensure and strengthen social development should be practicaloriented and tangible.
\end{abstract}

\section{GíRiș}

Sürdürülebilirlik içerdiği boyutlar bakımından, ulusal ve uluslararası sivil toplum örgütlerinden hükümetlere ve politikacılara, sosyal bilimlerden eğitim, sağlık, spor ve çevre bilimlerine kadar uzanan çok geniş bir alanı kapsamaktadır. Bundan dolayı, sürdürülebilirliğin kavramsallaştırılması üzerine yapılan çalışmalarda farklı bilim dalları, farklı yaklaşımlar ve farklı tanımlar geliştirmiştir (Yeni, 2014).

Sürdürülebilirlik kavramı üzerine oldukça kapsamlı yapılan tüm soyut açıklamaların günlük yaşamımızda daha somut bir şekilde eğitim, çevre, ekonomi, gençlik, sağlık, spor gibi farklı alanlarda da hayata geçirilebilmesi için kavrama ilişkin bir takım sınıflandırıcı ve açıklayıcı alt kavramlara da gereksinim vardır. Bu açıklayıcı ve sınıflandırıcı kavramlar, bir taraftan sürdürülebilirlik kavramının en genel hatlarıyla şekillenmesini sağlarken diğer taraftan da toplumsal kalkınmanın sağlanması ve sürdürülebilirliğin garanti altına alınması sırasında, ilgili alanlardaki politikalar ve ilkelerin belirlenmesi ve uygulanması sürecinde karar vericilere ve uygulayıcılara rehberlik edecektir.

Genel anlamıyla sürdürülebilirlik kavramı, belirsiz bir süre boyunca bir durum veya sürecin sürdürülebilme kapasitesini ifade ederken, bu genel anlamıyla sürdürülebilirlik, pek çok farklı şekillerde algılanabilmekte ve tanımlanabilmektedir (Temel, 2016). İfade ettiği anlam bakımından değerlendirildiğinde ise sürdürülebilirlik kavramı; "devamlı olma hali", "daim olma", "süreklilik arz etme" durumuna işaret etse de, sözcügün sahip olduğu bu anlamlarından farklı olarak, isteğe bağlı dışsal bir etkene bağımlılığı da ifade etmektedir. Ayrıca "bir şeyin sürekli olması" durumu, herhangi bir iradeden bağımsız olarak da gerçekleştirilebilirken, "sürdürülebilir olması", bütün koşullar uygun olması durumunda bile 
Balcı, V., Gök, S., ve Akoğlu, H. E. (2018). Türkiye'nin ulusal gençlik ve spor politikalarının, sürdürülebilirliğin sosyal boyutuyla incelenmesi. Spor Bilimleri Araştırmaları Dergisi, 3(1), 9-22.

bir iradenin bu doğrultuda tercih kullanmasına bağlıdır. Bu yüzden de uluslararası alanda, tek başına bir anlam ifade etmeyen sürdürülebilirlik kavramı daha çok, doğal kaynakların kullanımı, çevre kirliliğii, ekonomi, sosyal, çevresel, kalkınma gibi doğrudan insan iradesine ve edimlerine bağlı kavramlarla ilişkili olarak kullanılmaktadır (Akgül, 2010).

Sürdürülebilirlik kavramını tam olarak değerlendirebilmek için kavramın derinliği ve karmaşıklığını anlamanız önemlidir. Le'le ve Norgaard (1996) sürdürülebilirliği "bir süre boyunca azaltılmış bir şeyi sürdürme kabiliyeti” olarak tanımlamıştır. Bununla birlikte, bilimsel bir bağlamda yapılan bu tanımın, hangi süre boyunca, hangi toplumsal süreçle ve hangi amaçların karşılıklı olarak sürdürülmesi gibi sorulara yol açtığını ortaya koymaktadır (Kjell, 2011).

İnsanlığın gelecek kaygısını içerisinde barındıran sürdürülebilirlik kavramı, bilim insanları tarafindan yapılan kavramsal her açıklamada "gelecek ve gelecek nesiller"le ilişkilendirilmektedir. "Ortak Geleceğimiz” başlıklı Brundtland Raporu'nda (1987) sürdürülebilirlik şu şekilde açıklanmaktadır: "İnsanlık, doğanın gelecek nesillerin ihtiyaçlarını karşılama yeteneğini tehlikeye sokmadan, günlük ihtiyaçları temin ederek, kalkınmayı sürdürülebilir kılma yeteneği ve becerisine sahiptir" (Evren, 2016). Bu açıklamaya göre; sürdürülebilirlik, sürdürülebilir kalkınmanın nihai temel amacıdır ve sürdürülebilir kalkınma ile ulaşılmak istenen “durumu” ifade etmektedir (Üçer, 2017).

Sürdürülebilirlik hangi durumlarda başarıya ulaşacaktır diye düşünüldüğünde ise, tüm insanların temel ihtiyaçlarının ve kaliteli yaşam arzularının karşılandığ 1 , her insan için yaşam kalitesinin arttırıldığı, aynı zamanda ekosistemlerin ve her canlının kendini yenilemelerine imkan tanındığı, evrenin yaşam destek sistemlerinin korunduğu ve bu koşulların gelecek nesiller için de teminat altına alındığı durumlarda başarıya ulaşacaktır (Üçer, 2017). Sürdürülebilirlik anlayışı ile bir toplumun yaşam kalitesi düşürülmeden tüketim toplumu olmaktan çıkarılıp, evrensel açıdan dayanışma içinde olan, çevresel yönetim, toplumsal sorumluluklar ve ekonomik çözümleri amaçlayan hedefler ortaya konulmaktadır (Özmehmet, 2007). Sürdürülebilir kalkınma genellikle tüketim oranının yenilenme, restorasyon ya da eski oranına eşit olduğu noktaya kadar doğal kaynaklardan faydalanma yöntemi olarak tanımlanır. Sürdürülebilirlik tarafından sunulan temel etik değer, özellikle adaletsiz sömürünün önlenmesi olan sosyal adalettir (Winston, 2011).

Sürdürülebilir kalkınma yaklaşımı, insan sağlığını ve doğal dengeyi koruyarak sürekli bir ekonomik ve toplumsal kalkınmaya imkan verecek biçimde, doğal kaynakların akılcı bir şekilde yönetimini sağlamak ve gelecek nesillere uygun bir doğal, fiziki ve sosyal çevre/ortam bırakma anlayışıdır. Bu tür bir yaklaşım, gelişmenin ya da kalkınmanın her bir sürecinde, küresel anlamda ekonomik, sosyal ve çevresel politikaların birlikte ele alınmasını gerektirmektedir (Güzel, Çoknaz ve Noordegraaf, 2009).

Kavramsal olarak değerlendirildiğinde sürdürülebilir kalkınma kavramı, günümüz ve gelecek nesiller için gerekli olan çevrenin korunması, ekonomik büyüme ile eşitlik ve sosyal adaletin devamlılığının sağlanması olmak üzere üç temel unsuru içermektedir. Gerek politik alan gerekse sosyal alanda kabul gören ve önemli bir araştırma ve politika konusu haline gelen sürdürülebilir kalkınma kavramı, mevcut ve gelecekteki olası çevresel, ekonomik ve sosyal sorunları çözümleyecek ve önleyecek güce sahiptir. Bu gücünden dolayı da sürdürülebilirlik 
Balc1, V., Gök, S., ve Akoğlu, H. E. (2018). Türkiye'nin ulusal gençlik ve spor politikalarının, sürdürülebilirliğin sosyal boyutuyla incelenmesi. Spor Bilimleri Araştırmaları Dergisi, 3(1), 9-22.

ve sürdürülebilir kalkınma anlayışı, temel bir hedef haline gelmiştir (Üçer, 2017). Sürdürülebilir kalkınma anlayışına göre sürdürülebilirlik, ülkelerin çevresel, ekonomik ve sosyal hedeflerindeki ortak paydayı göstermektedir ve geleceği de içeren bu ortak hedefler ise tüm insanların temel ihtiyaçları ile daha iyi bir yaşama ilişkin beklentilerin karşılanmasına yönelik imkânlar sunmaktadır (www.surdurulebilirkalkinma.gov.tr, 2017).

Sürdürülebilirlik kavramının genel hatları ile daha belirgin ve açıklayıcı ele alınması için "sürdürülebilirliğin üçayağı" ve "sürdürülebilirliğin daireleri” modellerinden yararlanılmaktadır (Evren, 2016). Sürdürülebilir kalkınmaya ilişkin yapılan çalışmalarda sosyal, çevresel ve ekonomik boyutların her birinin kendi içerisinde toplumsal gereksinimler, biyolojik çeşitlilik, üretim ve kültürel miras gibi önemli farklı konu başlıklarını dikkate alırken, bu konu başlıkları birbirinden bağımsız olarak değil, birbirleriyle etkileşim içinde ele almak gereklidir (Y1kmaz, 2011).

Sürdürülebilirliğin üçayağı modeli ilkesine göre; sürdürülebilirlik, ancak ekonomik, çevresel ve sosyal boyutta eş zamanlı ve eşit kalkınma ile mümkün olabilecektir. Bu modele göre; birbirine daimi bir ilişki zinciriyle bağlı olan sürdürülebilirliğin üç boyutu kısaca şu şekilde açıklanabilir: ekonomik boyut; mal ve hizmetlerin doğal kaynakların aşırı tüketimini engelleyerek üretim yapan bir sistemi işaret eder; çevresel boyut ise, çevreye zarar vermeksizin kendi kaynaklarını yönetebilen bir sistemi ön görmektedir. Sosyal boyutta da, insan hakları ve toplumsal kalkınma, kurumsal güçler, çevresel adalet, küresel yoksulluk ve vatandaş eylemleri arasındaki ilişkiler ele alınmaktadır. Sürdürülebilirlik bu üç boyut aracılığıyla, tüketim alışkanlıkları ve etik tercihlerde bireysel hareket etme yerine bilinçli ve sorumlu evrensel vatandaşlık kavramını savunmaktadır (Evren, 2016).

Toplumsal sürdürülebilirlik, dünyadaki hızla artan nüfus artışı, doğal afetler ve sosyal afetlere (terör saldırıları, göçler, savaşlar gibi) bağlı olarak çevresel, ekonomik ve sosyal boyutlarda sürdürülebilirliği olumsuz etkileyebilecek farklı bir takım sorunlarla karşı karşıya kalabilmektedir. $\mathrm{Bu}$ nedenle, sürdürülebilir toplumlar için gerekli ve uygun politikaların belirlenmesi ve bu politikaların eyleme dönüştürülmesi gereği ortaya çıkmaktadır.

"Sürdürülebilir bir toplum" amacını gerçekleştirecek politikaların belirlenmesi ve gerekli politikaların oluşturulmasının önündeki engellerden biri, toplum düzeyinde ulaşılmak istenen hedeflere ilişkin uygun politikaların somut şekilde belirlenememesidir. Sosyal sürdürülebilirlik göstergeleri, toplumun sürdürülebilirlik hedeflerine ulaşmada yol gösterecek ulusal politikaların belirlenmesinde oldukça etkin bir araç olarak yer alacaktır. Bu yüzden sürdürülebilirlik kavramı ve alt boyutları, kendine özgü bir toplumun veya mevcut devam eden herhangi bir sistemin devamlılığının sağlanması amacıyla uygulanabilirliği mümkün politikaları belirlemede ve eyleme dönüştürülmesi sürecinde her toplum tarafından kabul gören ve sürdürülebilirliğin bütünleştirmeye çalıştı̆̆ 1 çevresel, ekonomik ve sosyal sisteme ilişkin göstergelerin ortaya çıkarılmasında rehberlik edebilecek niteliktedir.

Sürdürülebilir kalkınma göstergeleri, çevresel, ekonomik ve sosyal yönlerden sürdürülebilir kalkınmayı sağlama yolunda karar alma sürecinde politika uygulayıcılarına yardımcı olan önemli araçlardır (TÜIKK, 2011). Sürdürülebilir kalkınma göstergeleri, tümleşik ve iç içe geçmiş olan sosyal, ekonomik ve çevresel sistemlerin iç yüzünü anlamak ve onların birbiriyle olan bağlantıları ve etkileşimlerine dair yeni kanaat ve bilgileri ortaya çıkarmak için oldukça 
Balcı, V., Gök, S., ve Akoğlu, H. E. (2018). Türkiye'nin ulusal gençlik ve spor politikalarının, sürdürülebilirliğin sosyal boyutuyla incelenmesi. Spor Bilimleri Araştırmaları Dergisi, 3(1), 9-22.

önemlidir. Göstergeler, ayrıca çevresel bütünleşme, kamusal katılımı ve nesiller arası ve nesiller içerisinde eşitliğe ilişkin kritik sorunları ele almak için de gereklidir (UNECA, 2011).

Kavramsal tanımlar içerisinde geçen "insan ihtiyacı" algısı, büyük ölçüde yaşanılan toplumlara bağlı olarak çeşitlilik gösterebilmektedir. Bazı toplumlar "ihtiyacı" yemek, içecek, barınma gibi daha çok temel insani ihtiyaçlar olarak algılarken; bazı toplumlarda ise sosyal güvenlik, halk sağlı̆̆ı, sosyal adalet ve eşitlik gibi durumlar ihtiyaç olarak algılanabilmektedir. Dolayısıyla ülkelerin gelişmişliği çoğu zaman refah düzeylerinin yanı sira toplumda demokratik katılım, temel insan haklarının garanti altına alınması ya da insanların özgür iradeleriyle tercihlerini yapması gibi kullanılan kavramlarla da bağdaştırılmaktadır.

Sürdürülebilirliğin sosyal boyutu, insan odaklı olup, sosyal ve kültürel sistemlerin devamlılığının sağlanmasında önemli rol oynamaktadır. Toplumun her bireyi için sağlanan sağlık, eğitim, uygun barınma koşulları, adalet dağıtımı, uygun koşullarda iletişim ve ulaşım gibi hizmetler sosyal dengenin bozulmasına meydan verilmeden sürdürülmesi, sosyal sürdürülebilirliğin dayanağını oluşturmaktadır. Gelişme ve kalkınmayı da içeren sosyal sürdürülebilirlik, gelişim ile toplumun din, hukuk sistemi, eğitim, gelenekler, iletişim gibi ekonomiden bağımsız bir temel üzerinde şekillenen değerler sistemi ve sosyal normları arasındaki dengeye odaklanır (Akgül, 2010).

Sosyal sürdürülebilirlik, güçlü bir sosyal uyum duygusuyla belirginleşen bir durumu ve temel hizmetlere (sağlık, eğitim, ulaşım, barınma ve rekreasyon) eşit ifade eder. Sosyal sürdürülebilirlik; sağlıklı ve yaşanabilir toplumları oluşturmak için resmi ve resmi olmayan süreçler, sistemler, yapılar ve ilişkiler ile mevcut kapasiteyi ve gelecek nesilleri etkin olarak desteklediği zaman ortaya çıkacaktır. Sosyal olarak sürdürülebilir toplumlar adaletli, demokratik ve iyi bir yaşam kalitesine sahip olacaktır (McKenzie, 2004).

Toplumsal kalkınma bağlamında sosyal yapıdaki gelişmeler için eğitim, sağlı, işgücü, istihdam, işsizlik, ücret ve kazanç, konut, sosyal güvenlik, kent-belediye nüfusları, katılımcılık, nüfus ve demografik yapıya ilişkin değişkenler kullanılabilmektedir. Böylece nitelikli ve sağlıkl1, işgücünün istihdam edildiği, gerek çalışanların gerekse emeklilerin yeterli düzeyde gelir seviyesine sahip olduğu ve bu yapının demografik göstergeler ve mekânsal dağılımı ile desteklendiği bir toplum yapısının oluşturulmasındaki eğilimi irdeleyebilmek mümkün olabilmektedir (Y1kmaz, 2011).

Toplumsal açıdan spor, çok yönlü olduğu için sadece bir kamu niteliği taşımamakta aynı zamanda da toplumun refah düzeyi ve ekonomik etkinliğinin önemli bir göstergesi olabilmektedir. Çoğu ülkelerde spor politikaları, elit sporcuların performanslarının arttırılması ve spora katılımın desteklenmesi gibi temel hedeflere odaklanmanın dışında, devlet ya da hükümetlerin belirledikleri sosyal, ekonomik ve çevresel hedeflerin de gerçekleştirilmesinde önemli derecede katkılar sağlayabilmektedir.

Ülkeler sporu, uygulamaya ve düzenlemeye yönelik hükümet politikası alanlarının yanı sıra fiziksel aktiviteyi ve sağlığı artırmak, çocuklarda obezitenin oluşmasını engellemek, ekonomik kalkınmayı artırmak, kentsel dönüşümün gerçekleşmesini desteklemek, sosyal hayata katılımı artırmak ve toplumsal gelişimi güçlendirmek, sosyal dışlanma ile mücadele 
Balcı, V., Gök, S., ve Akoğlu, H. E. (2018). Türkiye'nin ulusal gençlik ve spor politikalarının, sürdürülebilirliğin sosyal boyutuyla incelenmesi. Spor Bilimleri Araştırmaları Dergisi, 3(1), 9-22.

etme gibi daha geniş politikaları şekillendirmek için bir araç veya yol olarak da kullanmaktadırlar (Hoye vd., 2015).

Bir sosyal kategori olarak gençlik, ekonomik ve sosyal açıdan çocukluktan yetişkinliğe geçiş dönemi olarak kabul edilmekte ve farklı toplumlarda hatta aynı toplumun farklı kesimlerinde belirli sosyo-kültürel, kurumsal, ekonomik ve politik boyutlara bağlı olarak farklı biçimlerde de ele alınabilmektedir. Bireyin en çok toplumsallaştı̆g 1 gençlik döneminde, bireyin sosyal gelişimlerini sağlamaya yönelik politikaları belirlemek ve bu politikalara uygun hizmetlere ülkedeki tüm gençlerin erişebilmesini sağlamak devletin hassasiyetle üzerinde durması gereken konulardan birisidir (Certel, 2010).

Türkiye' de gençlik ile ilgili devlet tarafından sağlanan imkanların tamamı, dayanağını temel olarak Anayasa' nın 58' nci maddesinden almaktadır ve gençler, daha çok geleceğin teminatı olarak görülmekte ve gençlere devleti koruma ve geliştirme görevleri verilmektedir. Gençlik politikalarının sosyal gelişim bağlamında rolü, gençleri yetişkinlik dönemindeki sorumluluk ve rollerine hazırlamak, bir yandan da gençler için üretken ve güvenli bir yaşam sunmak için gerekli olan ihtiyaçları sunabilmektir. Sosyal boyutta gelişmiş ve sosyal işlevselliğini kazanmış bir gençlik de, bir ülkenin toplumsal refahı için son derece önemlidir (http://www.mevzuat.gov.tr, 1982).

Bir sosyal ve kültürel sistem olarak gençlik ve spor alanlarında da sosyal sürdürülebilirlik kavramı, sağlıklı nesillerin yetiştirilmesi, halk sağlığının korunması, toplumsal barışın sağlanması ve sosyal uyumun arttırılması gibi oldukça önemli hedefleri kapsamaktadır. Bu kapsamda çalışmanın amacı, Türkiye' nin Ulusal Gençlik ve Spor Politikaları' nın, sürdürülebilirliğin sosyal boyutu açısından incelenmesidir.

$\mathrm{Bu}$ amaçla yapılan çalışmada; gençlik ve spor alanlarında uygulamaya yönelik belirlenen ulusal politikaların etkilerinin ve başarı düzeylerinin değerlendirilmesine ilişkin analitik incelemelerin de yapılabilmesi için çalışmanın bundan sonra ki bölümünde Türkiye'de gençlik ve spor alanlarında, sürdürülebilirliğin sosyal boyutunda yer alan sosyal göstergelerin, ulusal gençlik ve spor politikaları içerisinde stratejik olarak nasıl kavramsallaştırıldığı analiz edilmeye çalışılacaktır.

Yapılan literatür incelemesinde konuyla ilgili araştırmaların spesifik başlıklar altında (sağlık, çevre, eğitim, ekonomi vb.) incelendiği görülürken bu çalışmada daha geniş kapsamlı ve sosyal sürdürülebilirliği kapsayan (sağlık, eğitim, istihdam, eşitlik, barınma, güvenlik vb.) konular ile ilgili literatür taraması yapılmıştır. 
Balcı, V., Gök, S., ve Akoğlu, H. E. (2018). Türkiye'nin ulusal gençlik ve spor politikalarının, sürdürülebilirliğin sosyal boyutuyla incelenmesi. Spor Bilimleri Araştırmaları Dergisi, 3(1), 9-22.

\section{YÖNTEM}

Nitel araştırma modeline göre tasarlanan araştırmada durum analizi (case studies) deseninden yararlanılmıştır. Durum analizi; bir ya da daha fazla olayın, ortamın, programın, sosyal grubun ya da diğer birbirlerine bağlı sistemlerin derinlemesine incelendiği yöntemdir (Büyüköztürk vd., 2017) Bu doğrultuda araştırmanın amacına uygun olarak veri toplama yöntemlerinden doküman incelenmesi yöntemi kullanılmıştır. Doküman incelemesi; araştırılması hedeflenen olgu veya olgular hakkında bilgi içeren yazılı materyallerin analizini kapsar (Yıldırım ve Şimsek, 2013).

Bu kapsamında başta Birleşmiş Milletler Sürdürülebilir Kalkınma Komisyonu (UNCSD) ve Uluslararası Olimpiyat Komitesi Olimpik Hareket' in "Gündem 21 Sürdürülebilir Kalkınma için Spor Çalışmaları" olmak üzere sonrasında da çevre, eğitim, sağlık, spor, sosyal hizmetler, ekonomi ve sosyal bilim dallarında literatürde yayınlanmış makalelerdeki sürdürülebilirlik kavramları ile kavrama ilişkin sınıflandırıcı ve açıklayıcı alt kavramlar incelenmiş ve sürdürülebilirlik kavramının sosyal boyut alt kavramı ve göstergeleri belirlenerek, 26 Kasım 2012 tarihinde Bakanlar Kurulu tarafindan onaylanan ve 27 Ocak 2013 tarihli Resmi Gazetede yayınlanarak yürürlüğe giren ve halen yürürlükte olan Türkiye'nin Gençlik ve Spor Politikası Belgesi içinde bulunan gerek gençlik gerekse spor politikalarında sürdürülebilirlik için sosyal göstergelere ilişkin göstergeler tespit edilmeye çalışılmıştır.

Yapılan doküman incelemesi sonucunda elde edilen veriler betimsel ve içerik analizi yöntemine göre analiz edilmiştir. Betimsel analizde elde edilen veriler daha önceden belirlenen temalara göre özetlenmekte ve yorumlanmaktadır. İçerik analizinde ise betimsel analizde özetlenen ve yorumlanan veriler daha derin bir işleme tabi tutulur ve betimsel bir yaklaşımla fark edilemeyen kavram ve temalar keşfedilir (Yıldırım ve Şimsek, 2013). Analiz sürecinde önceden belirlenen tema ve alt temalara yenileri eklenerek temalardan alt temalara, alt temalardan kodlara ulaşılarak anlamlı bir bütünlük sağlanmaya çalışıllmıştır.

Sürdürülebilirlik göstergeleri, durumları kavramsallaştırarak ve eğilimleri vurgulayarak, karmaşık ve karışık bilgileri özetler, basitleştirir, nicelik kazandırır ve yönetilebilir düzeyde anlamlı bilgiye dönüştürür (Üçer, 2017). Bu özelliklerinden dolayı, sürdürülebilirlik değerlendirmeleri, bir taraftan politika yapıcılara ve/veya karar alıcılara, belirlenen politika hedeflerine ne ölçüde yaklaşıldığını ortaya koyarken diğer taraftan da çevresel, ekonomik ve sosyal boyutlarda zayıf ve kuvvetli temaların tespit edilmesinde ve geleceğe yönelik uygulama politikaların geliştirilmesine de yardımcı olmaktadır (Gazibey, Keser ve Gökmen, 2014).

\section{BULGULAR}

Araştırmada öncelikle, literatürde genel kabul gören ve UNCSD (2007) tarafindan oluşturulan göstergelerden faydalanılarak, gençlik ve spor alanlarında sürdürülebilirlik hedeflerinin değerlendirilmesi için kullanılabilmesi hedeflenen sosyal tema ve alt temalar ile göstergeleri tanımlanmış ve sonrasında da çizelge haline getirilmiştir (Tablo 1). 
Balcı, V., Gök, S., ve Akoğlu, H. E. (2018). Türkiye'nin ulusal gençlik ve spor politikalarının, sürdürülebilirliğin sosyal boyutuyla incelenmesi. Spor Bilimleri Araştırmaları Dergisi, 3(1), 9-22.

Tablo 1'de yer alan sosyal göstergeler ve temalardan esinlenerek gençlik ve spor alanlarında yer alan politikalar bu göstergelere göre bu çalışmada sınıflandırılmaya çalışılmıştır (Tablo 2 ve Tablo 3).

Tablo 1: Gençlik ve Spor alanlarında sürdürülebilirlik için sosyal göstergelerin oluşturulması

\begin{tabular}{|c|c|c|}
\hline $\begin{array}{l}\text { Sosyal Göstergeler } \\
\text { Temalar }\end{array}$ & Alt temalar & Göstergeler \\
\hline \multirow[b]{2}{*}{ Sosyal İçerme** } & Cinsiyet Eşitliği & Kadınların gençlerin ve çocukların sosyal hayata katılımı \\
\hline & Firsat Eşitliği / Dezavantajlılar & $\begin{array}{l}\text { Sunulan hizmetler herkesin eşit şekilde ayrım yapılmaksızın } \\
\text { faydalanması }\end{array}$ \\
\hline \multirow{3}{*}{ Eğitim* } & Eğitim Düzeyi & Lise ve dengi okul mezunu \\
\hline & Okuryazarlık & Yetişkin okuryazar durumu \\
\hline & Hayat boyu öğrenme & $\begin{array}{l}\text { Hayatın her döneminde bireyin bilgi, beceri, ilgi ve } \\
\text { yeterliliklerini geliştirmesi }\end{array}$ \\
\hline \multirow{3}{*}{ Sağlık* } & Sağlıklı Beslenme & Sağlıklı beslenme alışkanlıkları kazanma \\
\hline & Sağlık Hizmetleri & Her türlü sağlık hizmeti \\
\hline & Toplum sağllğ 1 & Sağlığı koruma \\
\hline İstihdam** & & $\begin{array}{l}\text { Özellikle kadın, dezavantajı bireyler ve gençlerin istihdamının } \\
\text { desteklenmesi }\end{array}$ \\
\hline \multirow{3}{*}{ Kültürrel Değerler** } & Aile & Aileye ait değerlerin korunması ve geliştirilmesi \\
\hline & Etik ve insani değerler & Evrensel değerlerin ve insan hakları \\
\hline & Kültür, spor ve sanat & Sanat, spor, kültürel kazanımlar \\
\hline $\begin{array}{l}\text { Eğlence ve serbest } \\
\text { zaman** }\end{array}$ & & Bireylerin boş zaman aktivitelerine katılımı \\
\hline \multirow{3}{*}{ Güvenlik* } & Her türlü bağımlılığa karşı önlemler & İnternet, madde bağımlı̆̆ ile mücadele \\
\hline & Şiddet & Her türlü şiddetle mücadele \\
\hline & Şike & Adil oyun anlayışı \\
\hline Barınma* & Yaşam alanları & Sosyal ve sportif donatıları olan yaşamsal alanlar \\
\hline
\end{tabular}

Tablo 1'de gençlik ve spor alanlarında sürdürülebilirlik için sosyal içerme, eğitim, sağlik, istihdam, kültürel değerler, eğlence ve serbest zaman, güvenlik ve barınma temaları belirlenmiştir. $\mathrm{Bu}$ temalara ilişkin cinsiyet eşitliği, firsat eşitliği/dezavantajlılar, eğitim düzeyi, okuryazarlık, hayat boyu öğrenme, sağlıklı beslenme, sağlık hizmetleri, toplum sağlı̆ğ, aile, etikve insani değerler kültür, spor ve sanat, her türlü bağımlılığa karşı önlemler, şiddet, şike ve yaşam alanları alt temaları oluşturulmuş ve alt temaların içeriklerine göre göstergeler sınıflandırılmıştır. 
Balcı, V., Gök, S., ve Akoğlu, H. E. (2018). Türkiye'nin ulusal gençlik ve spor politikalarının, sürdürülebilirliğin sosyal boyutuyla incelenmesi. Spor Bilimleri Araştırmaları Dergisi, 3(1), 9-22.

Tablo 2: Spor politikalarının sürdürülebilirliğin sosyal boyutu açısından değerlendirilmesinde kullanılabilecek sosyal göstergeler

\begin{tabular}{|c|c|c|}
\hline Temalar & Alt Temalar & Politikalar \\
\hline \multirow{2}{*}{ Sosyal İçerme } & Spor Tesislerine erişim & $\begin{array}{l}\text { * Kamu kurum ve kuruluşlarına ait tesislerin, günün her saatinde açık hale } \\
\text { getirilmesini ve tüm vatandaşlar tarafından kullanılabilmesini sağlamak. } \\
\text { *Spor tesislerinin yerlerinin belirlenmesinde, sporcuların ve halkın katılımını } \\
\text { kolaylaştıracak yerlere öncelik vermek ve bu yerlere etkin ulaşım olanaklarını } \\
\text { sağlamak. }\end{array}$ \\
\hline & Dezavantajlılar & $\begin{array}{l}\text { *Spor tesislerinin engellilerin erişimine uygun hale getirilmesi. } \\
\text { *Engellilerin sportif performanslarının arttırılmasına yönelik çalışmaların } \\
\text { yapılması. } \\
\text { *Eğitim kurumlarında engellilere yönelik faaliyetlere yer verilmesi. } \\
\text { *Engellilerin spor aracılığıyla rehabilitasyonlarının sağlanması. }\end{array}$ \\
\hline \multirow[b]{2}{*}{ Eğitim } & Spor Elemanları Eğitimi & $\begin{array}{l}\text { *Sporun her alanına destek verecek Uzman ve nitelikli teknik eleman } \\
\text { yetiştirilmesi } \\
\text { *Antrenörlerin eğitim düzeylerinin kalitesini yükselterek hizmet alanlarına } \\
\text { katkıda bulunmak. }\end{array}$ \\
\hline & Sporcu Eğitimi & $\begin{array}{l}\text { *Kamp eğitim merkezleri tesislerini ülke geneline yaygınlaştırmak } \\
\text { *Yetenekli sporcuların eğitim ve sportif çalışmalarını bir arada yürüteceği } \\
\text { sistemler geliştirmek } \\
\text { *Kamplardan ve müsabakalardan dolayı eğitim ve öğretimleri aksayan } \\
\text { öğrencilere ilave ders ve etüt programları uygulamak. } \\
\text { *Yeni eğitim sisteminde beden eğitimi ve spor dersleriyle ilgili müfredat } \\
\text { programlarını çocukların ve gençlerin gelişim düzeyleri ve beklentilerini göz } \\
\text { önünde bulundurarak yeniden düzenlemek. }\end{array}$ \\
\hline \multirow{3}{*}{ Sağlık } & Sporcu Sağlığı(Beslenmesi) & $\begin{array}{l}\text { *Sporcuların sağlıklı bir şekilde spora katılmalarının sağlanması. } \\
\text { *Spor yaralanmalarının önlenmesi ve tedavisinde gerekli tedbirlerin alınması. } \\
\text { *Sporcuların beslenme durumlarını özel olarak değerlendirerek spor diyetisyeni } \\
\text { eşliğinde beslenme programları hazırlamak. } \\
\text { *Dopingle mücadele konusunda eğitim çalışmalarını yaygınlaştırmak ve medya } \\
\text { aracılığıyla toplumu bilgilendirmek. }\end{array}$ \\
\hline & Dopingle Mücadele & $\begin{array}{l}\text { *Sporcuya ergojenik maddeler ve dopingin zararları hakkında bilgi vermek. } \\
\text { *Ulusal ve uluslararası spor kuruluşları ile uyumlu ve koordineli anti doping } \\
\text { önlemleri almak. Antrenörlere dopingle ilgili eğitim vermek. }\end{array}$ \\
\hline & Toplum Sağlığ1 & $\begin{array}{l}\text { *Obeziteyle mücadele çerçevesinde yapılan sportif çalışmalara destek vermek. } \\
\text { *Sağlık için spor yapan bireylere, çocuk ve gençlere destek ürünlerinin yanlış } \\
\text { kullanılmasını engellemek için eğitim çalışmaları düzenlemek. }\end{array}$ \\
\hline İstihdam & & $\begin{array}{l}\text { *Spor eğitimi veren üniversitelerin fakülte ve yüksekokullarından mezun } \\
\text { olanların sporla ilgili kurum ve kuruluşlarda istihdamının arttırılması. }\end{array}$ \\
\hline Kültürel Değerler & Spor Kültürü & $\begin{array}{l}\text { *Eğitim ve öğretim kurumlarında sporun geliştirilmesi ve yaygınlaştırılması. } \\
\text { *Küçük yaşlardan itibaren düzenli fiziksel aktivite alışkanlığı kazandırmak. } \\
\text { *Spor kültürünün benimsenmesine yönelik eğitici, bilgilendirici ve yönlendirici } \\
\text { çalı̈şmalar yapmak. } \\
\text { *Öğrencilere spor müsabakalarını yerinde izletmek, öğrencilerin seyirci kültürü } \\
\text { ve spor etiği konusunda eğitim almalarını sağlamak. }\end{array}$ \\
\hline Eğlence ve Serbest Zaman & & $\begin{array}{l}\text { *Kamu kurum ve kuruluşları ile özel sektörde çalışanlara yönelik spor alanları } \\
\text { oluşturmak ve serbest zamanlarında spor yapmalarını teşvik etmek. } \\
\text { *Yerleşim bölgelerinde insanların fiziksel aktivite yapacağı alanlar oluşturmak } \\
\text { ve halkın hizmetine sunmak. }\end{array}$ \\
\hline \multirow{2}{*}{ Güvenlik } & Sporda Şiddet & $\begin{array}{l}\text { *Sporda şiddetin önlenebilmesi amacıyla gereken yerlerde yaptırımlı önlemleri } \\
\text { almak. }\end{array}$ \\
\hline & Sporcu Hakları & *Sporcu, spor eğiticisi ve yöneticilerin tüm haklarını hukuksal açıdan gözetmek. \\
\hline
\end{tabular}

Tablo 2'de spor politikalarının sürdürülebilirliğin sosyal boyutu açısından değerlendirilmesinde kullanılabilecek sosyal göstergeler için belirlenmiş temalara göre (sosyal içerme, eğitim, sağlık, istihdam, kültürel değerler, eğlence ve serbest zaman, güvenlik ve barınma) alt temalara ayrılmıştır. Bu temalara ilişkin oluşturulan alt temalar Gençlik ve Spor Politikası Belgesi’nde yer alan spor politikaları içeriklerine göre sınıflandırılmıştır. 
Balcı, V., Gök, S., ve Akoğlu, H. E. (2018). Türkiye'nin ulusal gençlik ve spor politikalarının, sürdürülebilirliğin sosyal boyutuyla incelenmesi. Spor Bilimleri Araştırmaları Dergisi, 3(1), 9-22.

Tablo 3: Gençlik politikalarının sürdürülebilirliğin sosyal boyutu açısından değerlendirilmesinde kullanılabilecek sosyal göstergeler

\begin{tabular}{|c|c|c|}
\hline Temalar & Alt Temalar & Politikalar \\
\hline Sosyal İçerme & Cinsiyet Eşitliği & $\begin{array}{l}\text { *Cinsiyet eşitliğinin güçlendirilmesine ilişkin tedbirlerin alınması. } \\
\text { *Genç kadınların yaşamın her alanında desteklenmesi. } \\
\text { *Engelli gençlerin sosyal dışlanmaya maruz kalmalarının önlenmesi. } \\
\text { *Suç işleyen gençlerin topluma kazandırılması ve gençlerin suç davranışına } \\
\text { yönelmelerinin önlenmesi. } \\
\text { *Sokakta yaşayan gençlerin sorunlarının çözülmesi ve toplumla bütünleşmelerinin } \\
\text { sağlanması. } \\
\text { *Gençlerin ve toplumdaki diğer kesimlerin dezavantajlı bireylere karşı } \\
\text { farkındalıklarının arttırılması ve sosyal uyum süreçlerine aktif katılımı. } \\
\text { *Göç yoluyla yeni bir yaşam kurmaya çalışan ve uyum sorunu yaşayan gençlerin } \\
\text { sosyal gereksinimlerinin sağlanması. }\end{array}$ \\
\hline Eğitim & & $\begin{array}{l}\text { *Eğitim politikasının hak temelli, bilimsel verilere dayalı, esnek ve katılımcılığı esas } \\
\text { alan bir yaklaşımla uzun vadeli olarak planlanması. } \\
\text { *Eğitime erişimin arttırılması ve eğitimde firsat eşitliğinin sağlanması. } \\
\text { *Eğitim program ve uygulamalarının, analitik düşünen bireylerin yetişmesini } \\
\text { sağlayacak biçimde geliştirilmesi. } \\
\text { *Okullarda ve üniversitelerde fiziki ve beşeri altyapının güçlendirilmesi. } \\
\text { *Yaygın eğitim imkânlarının geliştirilmesi ve hayat boyu öğrenme anlayışının } \\
\text { güçlendirilmesi. } \\
\text { *Yurt dışı eğitim aracılığıyla gençlerin eğitim, kültür, bilgi düzeylerinin arttırılması } \\
\text { ve bunların topluma geri dönüşünün sağlanması. } \\
\text { *Genç kadınların eğitimin her kademesinde erkeklerle eşit düzeyde yer almasını } \\
\text { sağlamak. }\end{array}$ \\
\hline Sağlık & Toplum Sağlı̆̆1 & $\begin{array}{l}\text { *Gençlerin madde bağımlılı̆̆ı, sigara, alkol ve zararlı sonuçlar doğuran } \\
\text { oyunlar/bahisler gibi sağlığa zararlı alışkanlıklardan korunmasına dair tedbirlerin } \\
\text { yaygınlaştırılması. } \\
\text { *Gençlerin sağlığının korunmasına yönelik önlemlerin arttırılması. }\end{array}$ \\
\hline İstihdam & & $\begin{array}{l}\text { *Genç işsizliğini en aza indirmek için etkin mücadele yöntemlerinin geliştirilerek } \\
\text { sürdürülmesi. } \\
\text { *Gençlerin staj imkânlarının arttırılması ve staj kalitesinin uluslararası standartlara } \\
\text { uygun olarak geliştirilmesi. } \\
\text { *Kariyer danışmanlığı ve mesleki rehberlik hizmetlerinin daha etkin şekilde } \\
\text { geliştirilmesi. } \\
\text { *Çalışmayan gençlerin iş hayatına katılımını sağlamaya yönelik sosyal projelerin } \\
\text { geliştirilmesi.(beceri geliştirme ve meslek kazandırma gibi projelerin) } \\
\text { *Tam zamanlı çalışma hakları çerçevesinde evde çalışma, uzaktan çalışma, esnek } \\
\text { çalışma gibi çalışma stratejilerinin geliştirilmesi. } \\
\text { *Genç girişimciliğine olan teşvik ve desteklerin arttırılarak sürdürülmesi. }\end{array}$ \\
\hline \multirow{3}{*}{ Kültürel Değerler } & Aile & $\begin{array}{l}\text { *Ailelerin kendi çocuklarıyla yaşadıkları sosyal problemlerin üstesinden gelmelerini } \\
\text { sağlayacak önlemler almak. } \\
\text { *Ailevi değerlere gençler tarafindan sahip çıkılması, bu değerlerin korunması ve } \\
\text { geliştirilmesi. }\end{array}$ \\
\hline & Etik ve İnsani Değerler & $\begin{array}{l}\text { *Evrensel etik ilkeler ve ahlaki değerler konusunda gençlerin bilinçlendirilmesi. } \\
\text { *İnsan hakları bilinç ve kültürünün gençlere kazandırılması. }\end{array}$ \\
\hline & Kültür ve Sanat & $\begin{array}{l}\text { *Gençlerimize tarihimizin ve kültürel mirasımızın daha iyi tanıtılması. } \\
\text { *Gençlerin sanat faaliyetlerine katılımının arttırılması. } \\
\text { *Gençlere yönelik kültürel ve sanatsal faaliyetlerin sayı ve niteliğinin arttırılması. } \\
\text { *Ulusal ve/veya bölgesel düzeyde gençliğe yönelik yayın yapan TV kanallarının } \\
\text { nicelik ve nitelik olarak yeterli seviyeye ulaştırılması. }\end{array}$ \\
\hline Eğlence ve Serbest Zaman & & $\begin{array}{l}\text { *Yurtlarda sosyal, kültürel, sanatsal ve sportif aktiviteleri çeşitlendirmek ve } \\
\text { arttırmak. } \\
\text { *Gençlerin serbest zamanlarını değerlendirebileceği merkezlerin, faaliyetlerin, } \\
\text { etkinlik mekânlarının sayılarının arttırılarak hizmetin daha fazla gence ulaştırılması. } \\
\text { *Gençlik merkezleri etkinliklerinden çeşitli nedenlerle faydalanamayan gençlerin } \\
\text { önündeki engellerin kaldırılması. } \\
\text { *Gençlik ve izcilik kamplarının kapasitelerinin ve sayılarının arttırılması } \\
\text { *Gençlikle ilgili sivil toplum örgütlerinin kuruluş ve yapılanmalarının düzenlenmesi } \\
\text { ve desteklenmesi. }\end{array}$ \\
\hline Güvenlik & & $\begin{array}{l}\text { *Gençleri, madde bağımlılığı ve şiddetten uzak tutmak için bulundukları çevreleri ve } \\
\text { eğitim kurumlarını daha güvenli hale getirmek. } \\
\text { *Gençleri bağımlılık yapan maddelerden korumak için önleyici tedbirlerin alınması } \\
\text { ve bağımlı gençlerin tedavileri ile ilgili olarak çalışmaların yürütülmesi. }\end{array}$ \\
\hline Barınma & & *Güvenli, sosyal ve sportif donatıları olan kaliteli yurt imkânlarını arttırmak. \\
\hline
\end{tabular}

\section{Tablo 3'te gençlik politikalarının sürdürülebilirliğin sosyal boyutu açısından değerlendirilmesinde kullanılabilecek sosyal göstergeler için belirlenmiş olan temalara göre}


Balcı, V., Gök, S., ve Akoğlu, H. E. (2018). Türkiye'nin ulusal gençlik ve spor politikalarının, sürdürülebilirliğin sosyal boyutuyla incelenmesi. Spor Bilimleri Araştırmaları Dergisi, 3(1), 9-22.

(sosyal içerme, eğitim, sağlık, istihdam, kültürel değerler, eğlence ve serbest zaman, güvenlik ve barınma) alt temalar oluşturulmuştur. Belirlenen temalar ve alt temalar Gençlik ve Spor Politikası Belgesi’ nde yer alan gençlik politikaları içeriklerine göre sınıflandırılmıştır.

\section{TARTIŞMA ve SONUÇ}

Sosyal sürdürülebilirliğin tanımı zaten ölçülebilen bazı göstergeleri içerisinde barındırmaktadır. Bu, kesin olarak neyin ölçülmekte olduğunun belirsizliği hissi yaratabilir. Tanımın kendisinde göstergeler bulunduğundan, mantıksal olarak ölçüm çerçevesinin rolü bunları alt göstergelere ayırmaktan geçmektedir (McKenzie, 2004). Bununla birlikte sosyal sürdürülebilirlik göstergelerinin tanımlanmasında literatürde sürdürülebilirlik göstergelerine ilişkin genel olarak kabul edilen görüşler 1şı̆̆ında geliştirilmiş olan kavramsal çerçeve (çevresel, ekonomik ve sosyal) ile sürdürülebilirlik daireleri modeli (Evren, 2016) kullanılmıştır. $\mathrm{Bu}$ yaklaşım ile politika yapıcılara ve/veya karar alıcılara, sürdürülebilir toplum hedeflerinin, gençlik ve spor politikalarında da daha stratejik ve ölçülebilir bir biçimde yer verilmesi konusunda bir fikir verebileceği düşünülmüştür.

Toplumun her bireyi için sağlanan bu sosyal hizmetlerin de sosyal adalet ve eşitlik, insan hakları, ortak sorumluluk ve farklılıklara saygı bakış açısıyla sosyal dengenin bozulmasına imkan vermeksizin gerçekleştirilmesi sürdürülebilirlik yaklaşımı açısından önemli bulunmaktadır (Yeni, 2014). Sürdürülebilirlik araştırmaları toplumsal refahı arttırmak için politika üreticilere büyük katkıda bulunmaktadır. Sürdürülebilirlik, ortak hedefleri, karş1lıklı dayanışmayı, değerleri, sınırları ve dengeli uyum süreçleri gibi önemli kavramları kapsayan ve ana hatlarıyla özetleyen bir kavramdır. Sürdürülebilirliğin amacı çevreyi korumak, ekonomik kalkınma, insan refahı ve diğer hedefleri gerçekleştirmek ve yaymaktır (Kjell, 2011).

Her alanda olduğu gibi gençlik ve spor alanında da sürdürülebilir kalkınma hedeflerini değerlendirebilmek amacıyla geliştirilecek göstergeler için sosyal, ekonomik ve çevresel alanlara ait farklı farklı göstergelerin değerlendirilip bütünleştirilmesi gereklidir (Çelik, 2006). Çevresel, ekonomik ve sosyal boyutlar temelinde etkileşimli ölçme ve değerlendirmeye ilişkin sürdürülebilirlik göstergeleri, nicel veya nitel olabileceği gibi, ayrıca eğitim, sağlık, ekonomi, çevre, sosyal alanlar gibi farklı alanlar arasında bağlantı kurulmasında önemli rol oynamaktadır (Gazibey, Keser ve Gökmen, 2014). Ayrıca çevresel bütünleşme, kamusal katılımı ve nesiller arası ve nesiller içerisinde eşitliğe ilişkin kritik sorunları ele almak için de gereklidir (UNECA, 2011).

Yapılan değerlendirme sonucunda; "sosyal içerme", "eğitim”, "sağlık", “istihdam”, "barınma", "kültürel değerler”, "eğlence ve serbest zaman” ve "güvenlik" başlıklı göstergeler ve bu göstergelerin alt kavramlarını içeren sürdürülebilirlik için sosyal göstergeler belirlenmiştir. Ancak bu göstergelere yönelik belirlenen politikalar ve hedeflerin daha çok soyut açıklamalarla betimlenmiş olduğu görülmüştür. Bu durum, sosyal sürdürülebilir bir sistem olarak değerlendirilen gençlik ve spor alanlarında sosyal boyutta belirlenen ulusal politikaların uygulamaya yönelik ve somut hedefler içermesi, politikaların başarı düzeylerinin ve etkililiklerinin daha fazla artırılması açısından oldukça önemlidir. 
Balc1, V., Gök, S., ve Akoğlu, H. E. (2018). Türkiye'nin ulusal gençlik ve spor politikalarının, sürdürülebilirliğin sosyal boyutuyla incelenmesi. Spor Bilimleri Araştırmaları Dergisi, 3(1), 9-22.

McKeize’ ye (2004) göre sosyal sürdürülebilirliğin mevcut tanımında temel ana göstergeler yer almaktadır. Bu göstergelere dayanarak toplumların sürdürülebilirliğinin daha kolay ölçülebilmesi için tanımda yer alan "eğitim", "sağlık", "eşitlik", "barınma", "istihdam" ve "kültürel değerler" gibi ana göstergelerin alt temalara ayrılması gerektiğini belirmiştir. Bu çalışma sonucunda bu temel göstergeler alt temalara ayrılmaya çalışılmıştır.

Eğitim yoluyla, kültür ve toplumu sürdüren toplumsal bağlar güçlenirken, ortaya çıkacak olan sorunlarla başa çıkmaları için gelecek kuşaklar daha bilinçli bireyler olarak yetişmiş durumda olacaktır. Sürdürülebilir uygulamaların öğretilmesinin ilkokulda başlaması ve yükseköğretime kadar devam etmesi gerektiğini savunmuştur. Üniversiteler, sürdürülebilir uygulamaların araştırılması ve öğrenilmesi için birincil kaynaktır (Welch, 2012). Ülke olarak politika yapıcılar tarafından çocuk ve gençler içim ilköğretim eğitiminden yükseköğretime kadar, sürdürülebilir yaşamın gerekliliklerini bir yaşam biçimi haline getirecek politikalar ve hedefler oluşturması gerekmektedir.

Nüfus büyüklüğü ve yoğunluğuyla birlikte fiziksel çevrede ortaya çıkan bozulmalar, insanın zihinsel ve fiziksel sağlığını etkileyerek, ilişkilerin korunması ve sosyal işlevler üzerinde doğrudan etkili olmaktadır (Hoff ve Polack, 1993). Çevre bir dünya meselesi olarak gittikçe önem kazandığından sürdürülebilirlik ortak bir siyasi hedef olarak benimsenmiştir. 1960'da Ekonomik İşbirliği ve Kalkınma Örgütü (OECD), 'istihdam yaratmak ve yaşam standartlarını yükseltmek için üye ülkelerdeki en yüksek sürdürülebilir ekonomik büyüme ve istihdamı sağlayacak politikalar geliş̧irmek için adımlar atmıştır (McKenzie, 2004).

Ekonomik sermayedeki sınıf temelli farklılıklar, üst sınıfın gençlik ve spor alanında daha imtiyazlı yaşamalarına olanak sağlarken bu kişilerin pahalı sporlara katılımını sağlamaktadır. Alt sınıfların ise aynı imkanlara eşit şekilde sahip olmalarını engellemektedir. Bu kapsamda değerlendirildiğinde hükümetlerin politikaları oluştururken kişilerin imkânları eşit şekilde kullanmasına olanak sağlayacak politikalar koyması gerekmektedir (Wilson, 2002). Ancak bu araştırma da belirtildiği gibi eşit politikaların uygulama olanakları göz önünde bulundurularak daha gerçekleştirilebilmesi mümkün politikalara yer verilmesi gerekmektedir.

Hükümet yasaları, toplumsal, ekonomik ve çevresel değişimi müzakere eden bir araçtır ancak sürdürülebilirliğin gerektirdiği sistemik dönüşümün kendi başına nadiren yeterli olduğu görülmektedir. Toplumsal sürdürülebilirlik üzerine net bir odaklanmanın sosyal hizmet müfredatına ve mesleki gelişim programlarına dahil edilmesi halinde kurumsal düzenlemeler, politikalar ile bireyler arasındaki etkileşimin daha olumlu sonuçlar ortaya koyacağı düşünülmektedir (Welch, 2012).

Bu kapsamda "sürdürülebilir toplum" amacını gerçekleştirebilmek bakımından gerekli ve uygun olan politikaların belirlenerek oluşturulması ve bu politikaların Türkiye' nin ulusal gençlik ve spor politikaları aracıllğıyla eyleme dönüştürülmesi için daha somut ilke ve hedeflerle hareket edilmesi gereklidir. Tural ve Karakütük'ün (1991) de belirttiği gibi, politikalar, toplumsal olarak kalkınmaya yönelik alınacak kararları ve uygulanacak eylemlere yön vermek amacıyla konulan ilkeleri içermektedir.

Sonuç olarak, sürdürülebilir kalkınmayı etkileyebilecek unsurların belirlenmesi, spor yönetiminde etkin tüm kurum ve kuruluşların birbirleriyle işbirliğinin ve koordinasyonunun daha etkili olacağı beklenmektedir. Gençlik ve spor alanında daha somut sosyal boyut 
Balcı, V., Gök, S., ve Akoğlu, H. E. (2018). Türkiye'nin ulusal gençlik ve spor politikalarının, sürdürülebilirliğin sosyal boyutuyla incelenmesi. Spor Bilimleri Araştırmaları Dergisi, 3(1), 9-22.

hedeflerini içeren ulusal gençlik ve spor politikalarının hayata geçirilmesini gereklidir. $\mathrm{Bu}$ nedenle, Türkiye'de gençlik ve spor politikalarında ulusal ve uluslararası mevzuat, politika ve programlar temelinde çalışmaların saptanması ve değerlendirilmesi; varsa, çeşitli politikalar ve stratejiler arasındaki örtüşmelerin belirlenmesi ve uygulanması, toplumsal kalkınma açısından sürdürülebilirliğin sosyal boyutunun gereklerinin yerine getirilmesi için önemlidir.

\section{KAYNAKLAR}

Acar, H. (2008). Türkiye'nin ulusal gençlik politikası nasıl yapılmalıdır?. Uluslararası İnsan Bilimleri Dergisi, $5(1), 1-20$.

Akgül, U. (2010). Sürdürülebilir kalkınma: Uygulamalı antropolojinin eylem alanı. Ankara Üniversitesi Dil ve Tarih Coğrafya Fakültesi Antropoloji Dergisi, 24, 133-164. DOI: 10.1501/antro_0000000023.

Aksu, C. (2011). Sürdürülebilir kalkınma ve çevre. Güney Ege Kalkınma Ajansı, [Erişim http://geka.gov.tr/Dosyalar/o_19v5e00u1ru61bbncf2qmlcpv8.pdf], Erişim Tarihi: 12 Eylül 2017.

Büyüköztürk, Ş., Kılıç Çakmak, E., Akgün, Ö.E., Karadeniz, Ş. ve Demirel, F. (2017). Bilimsel araştırma yöntemleri. 23. Basım. Ankara: Pegem Akademi.

Certel, E. (2010). Gençlik ve sosyal gelişim: gençlik örgütlerine katılan gençlerle bir araştırma. Yüksek Lisans Tezi. Hacettepe Üniversitesi, Ankara.

Çelik, Y. (2006). Sürdürülebilir kalkınma kavramı ve sağlık. Hacettepe Sağllk İdaresi Dergisi, 9(1), 19-37.

Evren, M. (2016). Sürdürülebilirlik, sürdürülebilir kalkınma ve ülkemizdeki mevcut durum, kalkınmada anahtar verimlilik. T.C. Bilim Sanayi ve Teknoloji Bakanlı̆ğ Verimlilik Genel Müdürlüğ̈̈ Dergisi, 335. [Erişim:https://anahtar.sanayi.gov.tr/tr/news/surdurulebilirlik-surdurulebilir-kalkinma-ve-ulkemizdekimevcut-durum/7320] Erişim Tarihi: 09 Ağustos 2017.

Gazibey, Y., Keser ve A., Gökmen, Y. (2014). Türkiye'de illerin sürdürülebilirlik boyutları açısından değerlendirilmesi. Ankara Üniversitesi SBF Dergisi, 6(3): 511-541. DOI: 10.16987/ausbf.93938.

Gürlük, S. (2010). Sürdürülebilir kalkınma gelişmekte olana ülkelere uygulanabilir mi?. Eskişehir Osmangazi Üniversitesi İ̈BF Dergisi, 5(2), 85-99.

Güzel, P., Çoknaz, D. ve Noordegraaf, M. A. (2009). Sürdürülebilir kalkınmanın çevre boyutunda uluslararası olimpiyat komitesi (IOC) uygulamaları ve olimpiyat organizasyonları kapsamında incelenmesi. Spor Bilimleri Dergisi, 20(2), 59-69.

Hoff, M. D., \& Polack, R. J. (1993). Social dimensions of the environmental crisis: Challenges for social work. Social Work, 38(2), 204-211. DOI: 10.1093/sw/38.2.204

Hoye, R., Nicholson, M., \& Haulihan, B. (2015). Spor ve politika meseleleri ve analizi. (Çev: Yrd. Doç. Dr. Cem Tınaz) İçinde M. Bakır (Eds.), 1. Basım, İstanbul: Beta.

IOC (International Olympic Coommitte). (2008). IOC spor, çevre ve sürdürülebilir gelişim rehberi. İstanbul: Türkiye Milli Olimpiyat Komitesi Yayınları.

Kjell, O. N. E. (2011). Sustainable well-being: a potential synergy between sustainability and well-being research. Review of General Psychology, 15(3), 255-266. DOI: 10.1037/a0024603.

McKenzie, S. (2004). Social sustainability: Towards some definitions. Australia: Hawke Research Institute Paper Series, (27), 255-266.

Özmehmet, E. (2008). Dünya'da ve Türkiye sürdürülebilir kalkınma yaklaşımları. E-Journal of Yasar University, 3(13), 1853-1856.

T.C. Kalkınma Bakanlığı, (2017). Sürdürülebilir kalkınma hakkında temel bilgiler. [Erişim: www.surdurulebilirkalkinma.gov.tr], Erişim Tarihi: 16 Nisan 2017.

Temel, F. (2016). ISO 500 listesindeki işletmelerin vizyon açıklamalarında yer verdikleri örgütsel çekicilik kavramlarının içerik analizi. Journal of Life Economics, International Peer-Reviewed and Opean Access Electronic Journal, 3(1): 131-140. DOI: 10.15637/jlecon.108 
Balcı, V., Gök, S., ve Akoğlu, H. E. (2018). Türkiye'nin ulusal gençlik ve spor politikalarının, sürdürülebilirliğin sosyal boyutuyla incelenmesi. Spor Bilimleri Araştırmaları Dergisi, 3(1), 9-22.

Tural, N. ve Karakütük, K. (1991). Eğitim politikası. TED Eğitim ve Bilim Dergisi, 15(82), 16-24.

UNECA (United Nations economic Comission for Africa). (2011). Sustainable development indicators. [Erişim: http://www1.uneca.org/Portals/sdra/sdra1/chap2.pdf] Erişim Tarihi: 12 Eylül 2017.

Üçer, A. Z. (2017). Kentsel politikaların belirlenmesinde bir araç: Sürdürülebilirlik göstergeleri. Çăgdaş Yerel Yönetimler, 26(1), 103-124.

Welch, J. (2012). Sustainability and social development: An integrative examination. International Consortium for Social Development, 34(1), 56-76

Wilson, T. C. (2002). The paradox of social class and sports involvement. International Review For The Soclology ff Sport, 37(1), 5-16. DOI: 10.1177/1012690202037001001.

Winston, M. (2011). Sustainability and social justice. International Journal of Business and Social Science, 2(16), 33-38. DOI: 10.1016/j.sbspro.2012.09.115.

Yazıcı, A. G. (2014). Toplumsal dinamizm ve spor. Uluslararası Türkçe Edebiyat Dergisi, 3(1), 394-405. DOI: 10.7884/teke. 280 .

Yeni, O. (2014). Sürdürülebilirlik ve sürdürülebilir kalkınma: Bir yazın taraması. Gazi Üniversitesi İktisadi ve Ídari Bilimler Fakültesi Dergisi, 16(3), 181-208.

Yıkmaz, R. F. (2011). Sürdürülebilir kalkınmanın ölçülmesi ve Türkiye için yöntem geliştirilmesi. Uzmanlık Tezi, Sosyal Sektörler ve Koordinasyon Genel Müdürlüğü.

Yıldırım, A.ve Şimşek H. (2013). Sosyal bilimlerde nitel araştırma yöntemleri. 9. Basım, Ankara: Seçkin Yayıncilık.

Yıldırım, A.ve Şimşek H. (2016). Sosyal bilimlerde nitel araştırma yöntemleri. 10. Basım, Ankara: Seçkin Yayıncilik. 